\title{
VITAROVAT
}

\section{Megjegyzések egy országos, átnézetes, térbeli talajinformációs rendszer kiépítéséhez}

\author{
TÓTH GERGELY és MÁTÉ FERENC
}

Európai Bizottság, Közös Kutatóközpont, Környezet és Fenntarthatóság Intézet, Ispra (Olaszország) és Pannon Egyetem Georgikon Mezőgazdaságtudományi Kar, Keszthely

Jelen cikkünkben a Szabó József-Pásztor László-Bakacsi Zsófia szerzőhármasnak az Agrokémia és Talajtan 54. számában (41-58. oldal) megjelent „Egy országos, átnézetes, térbeli talajinformációs rendszer kiépítésének igénye, lehetősége és lépései" címü vitaindító értekezéséhez, illetve az ott felvetett témához kívánunk hozzászólni.

Nagy munkára vállalkozott a szerzőhármas, amikor számba kívánta venni egy országos, átnézetes, térbeli talajinformációs rendszer kiépítésének igényét, lehetőségét és lépéseit. Az Agrokémia és Talajtan hasábjain megjelent vitaindító értekezés ennek a munkának ismertetését célozza.

A közlemény első részében kísérletet tesz összefoglalni azokat az igényeket, amelyek egy átnézetes térbeli talajinformációs rendszer kiépítését szükségessé tesznek, illetve megbecsüli a talajinformációk előállításának lehetőségeit. Továbbá összehasonlítást tesz három magyarországi térképi alapú talajinformációs rendszer között. A későbbiekben pedig áttér a cikk fö mondanivalójára, a Kreybig-féle térképek reambulációjának és digitális rögzítésének ismertetésére.

A cikk első részében több szempontból is megvizsgálja a címben felvetett kérdéskört, ugyanakkor némi hiányérzetünk is marad annak olvastával.

A bevezető első szembetünő ellentmondása, hogy ugyan több helyen is megemlíti a talajinformációk iránti „kifejezetten erőteljesen” növekvő társadalmi igényt, és erre hivatkozva tartja fontosnak új talajinformációk elóállítását, ennek ellenére mintha eleve lemondana az új adatok gyüjtésének, az adatbázisok kiegészítésének lehetőségéről (erre vonatkozóan a Kreybig térképek reambulálásához és kiegészítéséhez később mégis kivételt tesz). Meglepő, hogy ennek alátámasztásául csupán egy kimondottan trópusi, fejlődő országok viszonyaival foglalkozó cikkre (NACHTERGALE \& VAN RANST, 2002) hivatkozik, illetve egy USA-ra vonatkozó adatra (ZHU et al., 2001), ez utóbbira tévesen. (A hivatkozott eredeti cikk a már meglévő térképek felújitásánál alkalmazott hagyományos módszer lassúságát kéri számon, és amellett érvel, hogy az új felvételezésekre, ill. térképezésre fordított erőforrásokból célszerủ volna áldozni a felújitási munkák modern módszerekkel történő folytatására is.)

Megállapításai azért is sajnálatosak, mert ezekkel a környező országokhoz képest növekvő elmaradásunkat kezeli mintegy természetesnek vehető tényként. [Például Csehországban és Szlovákiában a részletes (1:10 000 léptékü) talajtérképek az országok

Postai cím: TÓTH GERGELY, DG Joint Research Centre, Institute for Environment and Sustainability, TP 280, I-21020 Ispra, Italy.E-mail: gergely.toth@jrc.it 
teljes területére elkészültek, míg a mezőgazdasági területekre még részletesebb (1:5000 léptékü) talajtérképek készültek (a szántókra szintén 100\%-os lefedettséggel). Távolabbi európai országokban, pl. Belgiumban, vagy Észtországban is hasonló a helyzet. (Forrás: Jones et al. 2005)] Ezen túlmenően, a bevezetőben felvetett olyan alkalmazások tudományosan megalapozott lehetőségét is kizárja így, mint például a földértékelés.

A későbbiekben a felvételezés során mérendő talajjellemzők kiválasztásának dilemmáját veti fel a cikk, rámutatva, hogy bizonyos másodlagos információk és pedotranszfer függvények alkalmazásával sok esetben új ismeretek nyerhetők a meglévő adatokból is. Ezzel a digitális talajtérképezés és származtatott információk előállításának előnyeit mutatja be, rátérve az információk térbeli kiterjeszthetőségének kérdésére is.

A kiterjeszthetőség és részletesség tárgyalása során sajnálatosan megáll a kistérségi/regionális szintnél (lásd 1. táblázat), nem foglalkozik a névleges és valós felbontás („effective map scale”) problematikájával, illetve több téves megállapítást tesz. Nem segíti a tisztánlátást, hogy az AGROTOPO, a KDTIR és az 1:10000-es térképekre egyaránt, mint nagyléptékü információkra utal, holott ezek léptéke eltérő (1. táblázat). [A méretarány, lépték értelmezésében a hazai szakirodalom nem teljesen egységes. Mi a Szabó és munkatársai által szintén követett szóhasználatot alkalmazzuk, a méretarányt a térképi távolság és valós távolság hányadosaként értelmezve: minél nagyobb ez a szám, annál nagyobb a méretarány.] Részben ez a tény, részben a tematikus igény indította el a nagyméretarányú térképezéseket az 1960-as években. Nyilván elírás a talajfolt térképek pontosságának növelésére javasolt módszer, miszerint minél kisebb inhomogenitást kellene ehhez figyelembe venni: valójában minél nagyobbat.

Talán szerencsés lett volna - már csak a bevezetőben felvetett talajtani problémákra való tekintettel is - a cikkben hivatkozott amerikai klasszifikáció ún. D3 szintjétől eltérő léptékü alkalmazásokat szintén tárgyalni. Ennek hiánya különösen amiatt zavaró, hogy egy tudományos dolgozathoz nem illö, meglehetősen szubjektív táblázaton, és az abból levont nagyon hiányos és sokban téves következtetésen kívül a cikk más részeiben sem találkozunk azokkal a fontos kérdésekkel, amik a címből és a témafelvezetésből következően elvárhatók lennének.

Éppen ezért érdemes röviden áttekinteni a talajtérképek méretarányára és alkalmazhatóságára vonatkozó nemzetközi és hazai elöírásokat és gyakorlatot.

WESTERN (1978) alapvető munkájában összeveti a különböző országokban a talajtérképezéskor vett mintasürüséget a nyomtatásban megjelenő térképek léptékével. Öszszegzéséből kiderül, hogy az Európában végzett térképezések mintasürüsége az 1:10.000 méretarányú térképezés során $0,2-8$ minta/ha. Korábban a Szovjetunióban ábrázolták nagyméretarányú térképeken az ennél hiányosabb mintasürüséggel nyert talajinformációkat, ugyanakkor Hollandiában még az 1:25.000 méretarányú ábrázolású térképekhez is megközelítőleg egy-hektáronként mintázzák a talajokat. Ebből a szempontból, nemzetközi összevetésben, az 1:10.000 méretarányú térképeink szelvénysürüsége is növelhető volna, míg a Kreybig térképezés során feltárt szelvények sürüsége csupán hozzávetőleg 1:100.000 léptékü térképi ábrázolást engedhetne. [Az átnézetes talajismereti térképezés Kreybig Lajos által írt módszerkönyvében (KREYBIG, 1937) egyetlen sor sincs a felvételezés részletességéröl. A személyesen Kreybig által felvételezett lapok (Polgár-folyás 96, Szentmargittapuszta 118, Egyek-Tiszacsege 148) szolgálhattak iránymutatásul a felvételezés sürüségére. A nyilvánvalóan nagyon fontos kunhegyesi lap területén közel 400 reprezentatív szelvény van, de találkozunk nagy- 
számú, 40-50 szelvény alapján szerkesztett térképpel is. Mindenesetre le kell szögezni, hogy egy talajtérkép nem attól huszonötezres, hogy egy huszonötezres topográfiai térképre rajzoljuk.] Ez volna a reális ábrázolási lépték, még az ún. nem reprezentatív szelvényeket figyelembe véve is. [A Kreybig térképezés során az információsürítéshez alkalmazott nem reprezentatív talajszelvények használatát egyedi megoldásnak nevezni szintén megkérdőjelezhető. A hagyományos talajtérképezés gyakorlata régen ismeri az egy-két ásónyomnyi vagy néhány deciméternyi ellenőrző pontokat (prikopkák), amelyekből néhány segíti a reprezentatív talajszelvényekkel jellemzett foltok határának megállapítását. Azáltal, hogy ezekhez vizuális kép és emlékezet alapján valamely reprezentatív szelvény számát hozzárendelik, a valóságosnál részletesebb felvétel illúzióját keltik. Még a jobbik eset, amikor helymegjelölés nélkül, a reprezentatív szelvény mellé ábrázolják az ilyen pontok sorát.]

Ezt támasztja alá DENT és YOUNG (1981) nemzetközi referenciaként kezelt munkája, LEGROS (1996) föképp francia nyelvterületeken használatos térképezési útmutatója, illetve más nemzeti talajtérképezési útmutatók és módszertani közlemények is (CURLIK \& Surina, 1998; GarkuSA, 1958; Hengl \& HuSNJAK, 2006; RASiO \& Vianello, 1995). Az 1. táblázat a különböző országok, illetve szerzők talajtérképezésre és a térképek alkalmazására vonatkozó ajánlásai alapján készített összehasonlítást mutatja.

Hazánkban a nagyméretarányú térképezés módszereit általánossá tevő útmutató (BARANYAI et al., 1989) rögzíti, hogy a gyakorlati igényeknek a „,nagyméretarányú, 1:10.000 léptékü talajtérkép felel meg”. A nagyméretarányú talajtérképezés során, többek között a Kreybig-féle 1:25.000 méretarányú átnézeti talajismereti térképek tanulmányozását, valamint az 1:100.000 méretarányú agrotopográfiai térképek hasznosítását is javasolva.

A nagyméretarányú, vagyis a legalább 1:10.000 léptékü térképek iránti gyakorlati igényeket nyolc pontban ki is fejti a hazai talajtérképezési útmutató. A nagyméretarányú térképek készülnek kifejezetten a (1) termőhelyi értékszámok megállapításához; (2) racionális földhasználat kialakításához, termőtájak kialakításához; (3) természeti viszonyok stressz-helyzeteihez alkalmazkodó lehetőségek megállapításához; (4) a talaj termékenységét megőrzését és fokozását célzó intézkedések meghozatalához (meliorá-

\section{1. táblázat}

A talajtérképezés célja, a mintavételi sürüség és talajtérképek méretarányának összefüggései*

\begin{tabular}{|l|l|c|c|}
\hline A talajtérkép léptéke & \multirow{2}{*}{$\begin{array}{l}\text { Az alkalmazás célja és } \\
\text { szintje }\end{array}$} & $\begin{array}{l}\text { Egy mintavétellel } \\
\text { jellemzett terület } \\
\text { (ha) }\end{array}$ & $\begin{array}{l}\text { A közölt térképek } \\
\text { méretaránya }\end{array}$ \\
\cline { 1 - 3 } Preciziós & Speciális, végrehajtási & $<1$ & $>1: 1000$ \\
\cline { 3 - 4 } & szint & $1-50$ & $1: 1000-1: 10.000$ \\
\hline Táblaszintü/helyi & Általános és speciális, & $50-1000$ & $1: 10.000-$ \\
tervezési szint & & $1: 100.000$ \\
\hline Regionális & Általános, tervezési & $1000-5000$ & $1: 100.000-$ \\
& szint & & $1: 250.000$ \\
\hline Országos/kórségi & Általános, tájékoztató & $>5000$ & $<1: 250.000$ \\
\hline
\end{tabular}

* Baranyai et al. (1989), Dent \& Young (1981). Legros (1996), Curlik \& Surina (1998), Garkusa (1958), Hengl \& HusnjaK (2006), Rasio \& Vianello (1995) Szabolcs (1966), valamint WESTERN (1978) felhasználásával 
ció, talajvédelem, vízrendezés, öntözés, részletes vizsgálatok meghatározása stb.); (5) talajtani szakvélemények elkészítése; (6) degradációs folyamatok előrejelzéséhez, megelözéséhez, kiküszöböléséhez, mérsékléséhez; (7) más irányú földhasználat területigényének kielégítése során a jó minőségü termőterület védelméhez; (8) környezet- és természetvédelmi feladatok meghatározásához.

Nagyméretarányú új térképek készítésének és térképfelújítások légifotókkal támogatott költségtakarékos módját, SZILÁGYI ÉS JUHÁSZ (1988) módszertani munkája részletezi, szintén 1:10.000 léptéktől tekintve helyi léptéken alkalmazhatónak a talajtérképeket.

A meliorációs tervezés során alkalmazott távérzékelési eljárások módszertanát tartalmazó útmutató (HÁRSFALVAI et al., 1990) rögzíti, hogy az 1:25.000 méretarányú térképeket a térségi tanulmánytervek ábrázolásánál használják, míg a „kivitelezési ütem feladatainak meghatározásánál viszont legalább $\mathrm{M}=1: 10.000$ méretarányú aktualizált térképek vagy helyszínrajzok szükségesek".

Mivel - amint az a fentiek alapján is elmondható - az adatsürüség és az ezen alapuló térképi ábrázolás léptéke meghatározza a felhasználási lehetőségeket, ezért, a további félreértéseket elkerülendő tisztázni kívánjuk, hogy a KDTIR rendszer átnézetes, de nem nagyméretarányú, így helyi léptékünek nem elég részletes térbeli talajinformációs rendszer.

A vitaindító cikk hangsúlyos részét képző, a KDTIR rendszer alapját adó Kreybigtérképek reambulációjának és digitalizálásának módszertani leírása régóta várt és haszonnal forgatható munka lehetne. Kár hogy a bemutatás nem tér ki olyan alapvető kérdésekre, mint a talajfolt határok térbeli pontossága, illetve megbízhatósága, tematikus pontosság a térképezett szelvényekkel és talajjellemzőkkel összefüggésben, vagy például összevetés az eredeti térképezés korabeli vizsgálati módszereket illetően is. Remélhetőleg a cikk végén ígért tervezett további közlemények tartalmazni fogják ezeket az alapvető információkat is.

A cikk nagy értéke, hogy a Magyarországon ez ideig csak kevésbé alkalmazott, digitális információkkal támogatott talajtérképezési eljárásokkal is foglalkozik. Jó volna látni, hogy az eddigi elszigetelt próbálkozások (pl. DoBOs et al., 2005; ILLÉs et al., 2003; SEBÖK, 2002; HERMANN et al., 2005) széles tudományos összefogással a hazai talajtérképezési módszertan megújításának támogatására világosan megfogalmazott célú és tartalmú együttmüködéssé formálódnak.

Ez azért is volna üdvözlendő, mert az európai Területi információs infrastruktúrához (COM, 2004) illeszkedően, hazánkban is megvalósításra vár a térbeli adatok alkalmazhatóságának összehangolási stratégiája, benne a Talaj Téradat Infrastruktúrára vonatkozó elemekkel. A hazai Talaj Téradat Infrastruktúrának több léptékü, interneten keresztül hozzáférhető és sokoldalúan alkalmazható talajinformációkat kell tartalmaznia, ennek megtervezése és kiépítése a közeljövő sürgető feladata. Mindeddig ugyanakkor csak kevés országos, átfogó projekt fektetett hangsúlyt arra, hogy a talajtani információkat valóban az INSPIRE (COM, 2004) elveknek - felhasználó centrikus-, hálózatos szolgáltatás, adatminőség és alkalmazhatóság stb. - megfelelően, az egyéb térbeli adatokkal (pl. kataszteri, domborzati adatok) együtt értelmezze. (Ilyen kivételek a „D-e-Meter” és „4F” projektek. Lásd: TÓTH, 2003 GAÁL et al., 2003; VASS et al., 2003; NÉMETH et al., 2006).

Mindent összevetve igen tiszteletreméltó törekvés az átnézetes talajismereti térképekben foglalt ismeretanyagnak a korszerü módszerekkel történő feldolgozására, jobb 
kiaknázására, hozzáférhetővé tételére (netalán helyenként kiegészítésére) való módszer és program kidolgozása. A Szabó és munkatársai által javasolt korszerű alapokon kialakítható térbeli talajinformációs rendszer azonban nagyon távol állana a helyi, ill. táblaszintü alkalmazási lehetőségektől, nem szolgálhatja a nagy részletességü térinformatikai alapok iránti hangoztatott nagy társadalmi igényt. Mindenesetre a Kreybig térképek anyagára támaszkodó százezres agrotopo, kétszázezres és félmilliós genetikai, valamint a különböző kisméretarányú müvelhetőségi-, humuszkészlet-, tápanyagkészlet-, vízgazdálkodási-, talajminőségi-, talajérzékenységi- stb. térképek részletessége a léptéknek (esetenként bőven) megfelelő.

A cikkben felvetett és azokon túlmutató igények miatt is kívánatos lenne a szellemi és anyagi kapacitásokat az ország mezőgazdasági területének kétharmadára elkészült, a helyi alkalmazások sorát valóban lehetővé tevő, nagyléptékü térkép- és adatanyag már megindult, ilyen irányú feldolgozására, annak kiteljesítésére is fordítani, mivel annak szakmai tartalma messze meghaladja az átnézetes talajismereti térképekét. Mert például amíg a Kreybig-térképek foltjai a sav-bázis viszonyokat három fokozatban, a vízgazdálkodást pedotranszfer útján kapott öt fokozatban és a szikesedést három fokozatban, ezenkívül a kövességet és a sekély termőréteget tartalmazzák, addig a nagyméretarányú üzemi talajtérképek ezen kívül is még egy sor további talajparamétert és a talajtulajdonságok valóságos kombinációját és annak dinamikáját is kifejező tudományos talajosztályozási egységek megnevezését is, szolgálva ezáltal a talajok multifunkcionalitásával kapcsolatos információ-igények jobb kielégítését is.

Mivel Magyarországon egy jól strukturált, különböző léptékü és tartalmú információval bíró - ezért sokoldalúan használható - talajtani információs rendszer, illetve egy egységes talajtani téradat infrastruktúra kiépítésének lehetősége adott, ezért a talajtannal foglalkozók közös felelőssége, hogy az egyes kutatóhelyeken, állami és magánintézményekben meglévő tudást és információt miképp sikerül a széles felhasználói rétegek számára hasznosíthatóvá tenni. Ebbe az irányba tett, feltétlenül üdvözlendő lépés a KDTIR rendszer építése, amit a nagyméretarányú talajtérképek és helyi használatra alkalmas információs rendszerek szintén folyamatban lévő felújítására tekintettel, az átjárhatóság megteremtésének és összehangolt, célirányos alkalmazásoknak kell követni.

\section{Irodalom}

BARANYAI F. et al. (szerk.), 1989. Útmutató a nagyméretarányú országos talajtérképezés végrehajtásához. Agroinform. Budapest

COM, 2004. Az Európai Parlament és a Tanács irányelv javaslata, Területi információs infrastruktúra (INSPIRE) létrehozásáról a Közösség területén. Brüsszel, 2004. július 23. COM(2004) 516 végleges 2004/0175 (COD) http://inspire.jrc.it/ (2006 áprilisi elérés alapján)

CuRLík, J. \& SuRINA, B., 1998. Prirucka terénneho prieskumu a mapovania pod. Vyskumny ústav podnej úrodnosti. Bratislava

DENT, D. \& Young, A., 1981. Soil Survey and Land Evaluation. George Allen \& Unwin. London.

Dobos, E., Michéli, E. \& Montanarella, L., 2005. The development of a soil organic matter content database using $1000 \mathrm{~m}$ resolution DEM and MODIS data for a pilot area of Hungary. DSM 2004, Montpellier, 13-17 September 2004. Elsevier CD-ROM 
GAÁL Z. et al., 2003. D-e-Meter az intelligens környezeti földminősítő rendszer. In: Földminősítés és földhasználati információ. (Szerk.: GAÁl Z., MÁTÉ F. \& TóTH G.) 3-22. Országos konferencia kiadvány, Keszthely 2003. december 11-12.

GarkUSA, I. F. 1958. Pobevoje isszledovannyija pocsv. Gosz. Izd. BSzSzR Minszk.

HÁRSFALVAI M. et al., 1990. Útmutató a távérzékelési módszerek alkalmazására a meliorációs kiviteli tervezésben. Földmérési és Távérzékelési Intézet. Budapest.

Hengl, T. \& HusnJaK, S., 2006. Evaluating adequacy and usability of soil maps in Croatia. Soil Sci. Soc. Am. J. 70. 920-929.

Hermann, T., Makó, A. \& Tóth, G. 2005. An example of DSFM: Application for mapping of the function of 'food and other biomass production'. In: Meeting of the Digital Soil Mapping Working Group of the European Soil Bureau Network. Prague. October 14-15, 2005. (Közlésre elfogadva; www.eusols.jrc.it)

ILLÉS G. et al., 2003. Az Észak-Hanság termőhelyi viszonyainak modellezése „fuzzy”klasszifikáció és GIS eszközök felhasználásával. Acta Agraria Kaposváriensis. 7. (3) 45-68.

JoNES, R. J. A. et al., 2005. Soil Resources of Europe. European Soil Bureau Research Report No. 9. $2^{\text {nd }}$ ed.. Office for Official Publications of the European Communities, Luxembourg.

KREYBIG L. 1937. A M. Kir. Földtani Intézet talajfelvételi vizsgálati és térképezési módszere. Budapest.

LANDON, J. R., 1984. Booker Tropical Soil Manual: A Handbook for Soil Survey and Agricultural Land Evaluation in the Tropics and Subtropics. Longman. New York.

Legros, J. P., 1996. Cartographies des sols. De l'analyse spatiale á la gestion des territoires. Collection Gérer l'Environnement 10. Press Polytechniques et Universitaires Romandes, Lausanne.

NACHTERGale, F. \& VAN RANST, E., 2002. Qualitative and quantitative aspects of soil databases in tropical countries. In: Evolution of Tropical Soil Science: Past and Future. 87-98. Royal Academy of Overseas Sciences. Brussels.

NÉMETH, T. et al., 2006. Framework and components of a new land evaluation system in Hungary. Paper submitted to the $18^{\text {th }}$ World Congress of Soil Science, July 9-15, 2006. Philadelphia, Pennsylvania, USA.

RAsio, R. \& Vianello, G., 1995 Classificazione e cartografia del suolo. Editrice CLUEB Bologna. Italy.

SEBÖK T., 2002. Térinformatikával segített mezőgazdaság, avagy a talajtérképezés és a DEM hasznosíthatósága (Pest Megyei Földhivatal) GISOpen 2002, Székesfehérvár, 2002. március 11-13. http://193.224.99.232/vhost/gisopen/cd_2002/dokumentum/doc_html/sebok_t.htm

SzABOLCS I. (szerk.), 1966. A genetikus üzemi talajtérképezés módszerkönyve. OMMI. Budapest.

SZABÓ J., PÁSZTOR L. \& BAKACSI J., 2005. Egy országos, átnézetes, térbeli talajinformációs rendszer kiépítésének igénye, lehetősége és lépései. Agrokémia és Talajtan. 54. 41-58.

SZILÁGYI A. \& JuHÁsz I., 1988. Talajtani légifénykép-interpretáció. Módszertani útmutató nagyméretarányú genetikus talajtérképek készítéséhez. Földmérési és Távérzékelési Intézet. Budapest.

То́тн G., 2003 Fönntartható mezőgazdasági földhasználat: az integrált tervezés lehetőségei. Földrajzi Értesítő. 52. (3-4) 215-227.

VASS J. et al., 2003. A D-e-Meter Internet bázisú földminősítő rendszer információs technológiája. In: Földminősítés és földhasználati információ. (Szerk.: GAÁL Z., MÁTÉ F. \& TóTH G.) 57 77. Országos konferencia kiadvány, Keszthely 2003. december 11-12.

WeSTERN, S., 1978 Soil Survey Contracts and Quality Control. (Monographs on Soil Survey) Oxford University Press. Oxford.

ZHU, A. X. et al., 2001. Soil mapping using GIS, expert knowledge and fuzzy logic. Soil Sci. Soc. Am. J. 65. 1463-1472.

Érkezett: 2006. május 18. 